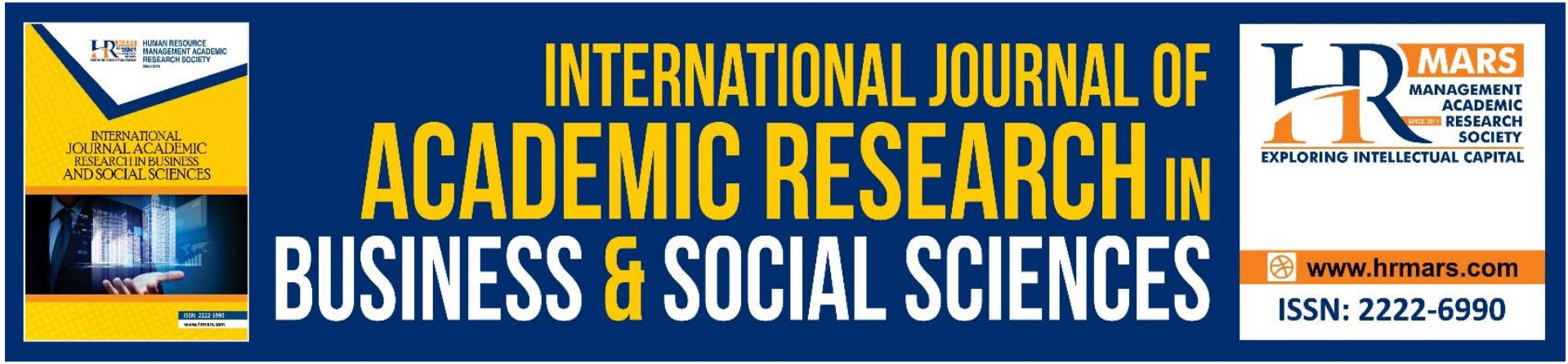

\title{
Measuring Organizational Commitment and Distributed Leadership: A Study in Malaysian Secondary Schools
}

Siti Aminah Zulkefli, Siti Salina Mustakim, Aminuddin Hassan, Arnida Abdullah, Ramli Basri

To Link this Article: http://dx.doi.org/10.6007/IJARBSS/v11-i7/10416

DOI:10.6007/IJARBSS/v11-i7/10416

Received: 03 May 2021, Revised: 05 June 2021, Accepted: 24 June 2021

Published Online: 01 July 2021

In-Text Citation: (Zulkefli et al., 2021)

To Cite this Article: Zulkefli, S. A., Mustakim, S. S., Hassan, A., Abdullah, A., \& Basri, R. (2021). Measuring Organizational Commitment and Distributed Leadership: A Study in Malaysian Secondary Schools. International Journal of Academic Research in Business and Social Sciences, 11(7), 78-88.

Copyright: @ 2021 The Author(s)

Published by Human Resource Management Academic Research Society (www.hrmars.com)

This article is published under the Creative Commons Attribution (CC BY 4.0) license. Anyone may reproduce, distribute, translate and create derivative works of this article (for both commercial and non-commercial purposes), subject to full attribution to the original publication and authors. The full terms of this license may be seen at: http://creativecommons.org/licences/by/4.0/legalcode

Vol. 11, No. 7, 2021, Pg. 78 - 88

Full Terms \& Conditions of access and use can be found at http://hrmars.com/index.php/pages/detail/publication-ethics 


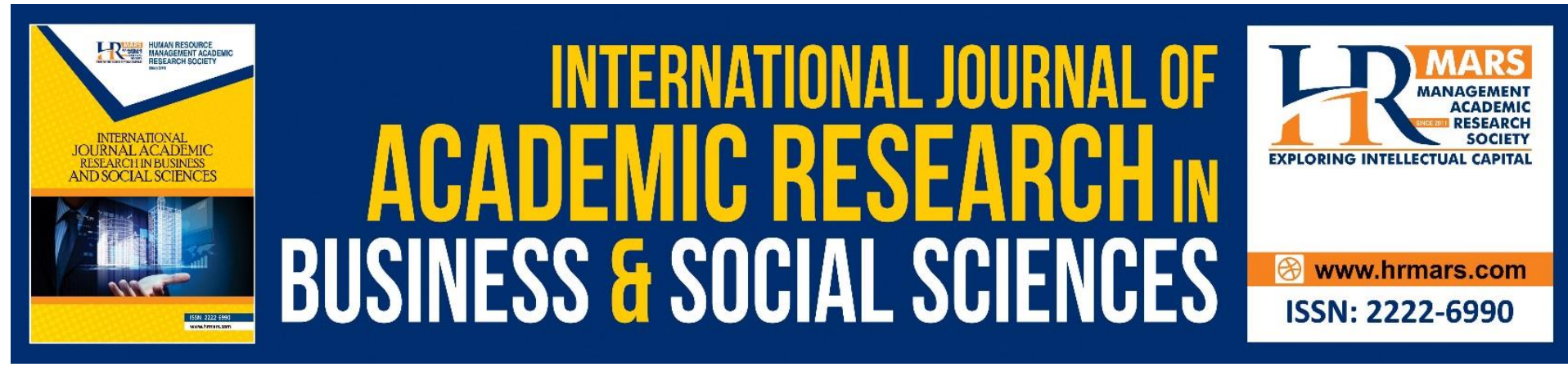

\title{
Measuring Organizational Commitment and Distributed Leadership: A Study in Malaysian Secondary Schools
}

\author{
Siti Aminah Zulkefli, Siti Salina Mustakim, Aminuddin Hassan, \\ Arnida Abdullah, Ramli Basri \\ Faculty of Educational Studies, Universiti Putra Malaysia, 43400, Seri Kembangan, Selangor \\ Malaysia \\ Email:mssalina@upm.edu.my
}

\begin{abstract}
The primary aim of this study is to determine the significant correlation between organizational commitment and distributed leadership among secondary school teachers in Malaysia. Using the instrument of Three-Dimensional Model (TCM) to measure the level of organizational commitment and Distributed Leadership Readiness Scale (DLRS) to measure the level of distributed leadership, the study specifically seeks to determine (1) the level of organizational commitment among secondary school's teachers in Malaysia, (2) the level of distributed leadership among schools' teachers in Malaysia, and (3) the relationship between distributed leadership and organizational commitment among secondary schools' teachers in Malaysia from 350 respondents selected using a simple random stratified sampling technique. Data presented in this study were analyzed using a descriptive statistic to explain the level of variables and inferential statistics to find a correlation between these variables. Findings indicated that there is a significant correlation between organizational commitment and distributed leadership with $r=.556, p=.000$ ) at the strong level.
\end{abstract}

Keywords: Organizational Commitment, Distributed Leadership, Teachers, Education, Secondary Schools

\section{Introduction}

One of the characteristics of teachers' quality is teacher must have a high commitment towards their job because high commitment among the employee is one of the key success factors of any organization (Ibrahim, Wan Sulaiman, Ibrahim, Abdul Malek, \& Bausing, 2018; Wan Sulaiman, Ibrahim, \& Mariappa, 2013; Metcalfe \& Dick, 2002). Organizational commitment among teachers is important because a committed teacher can produce more promising learning outcomes among students (Ling, 2016). As stated in Malaysia Educational Blueprint (MEB) (2013), good teachers alone are not enough. Teachers will periodically update their knowledge to keep up with current education advancement and they need to attend training to keep up with their necessary professional knowledge and skills (Mustakim, et. al., 2020). Other factors too, can boost organizational commitment among teachers. There are many environmental factors influence teacher's organizational commitment and the most 
common variable by several comprehensive studies is leadership practice among principal (Meyer \& Allen, 1997; Nguni et al., 2006; Ross \& Gray, 2006; Dee, Henkin, \& Singleton, 2006; Rehman, et al.,2012; Saeed et al., 2013). In an educational institution context, especially at school, principal leadership style influences teachers' commitment towards their organization.

Rather than leaders or their positions, duties, habits, and processes, distributed leadership refers to the leadership practice. Rather than being a product of one or more leaders' decisions, leadership practice emerges from interactions between leaders and subordinates. The focus of the second wave of MEB begins from 2016 until 2020 is to enhance teacher career pathway and progression, and for principal is to elevate the profession and move towards distributed leadership. And, the third wave of MEB starts from 2021 until 2025 by focusing on creating a peer-led culture of professional excellence among teachers and school leaders. Previous research has shown that supportive principals have a positive effect on teachers' organizational engagement, with teachers being more committed to the school when principals provide guidance, motivation, recognition, and specific school objectives (Nguni et al., 2006; Park, 2005; Tsui \& Cheng, 1999).

There are several definitions from scholars about distributed leadership. Elmore (2000) suggested the idea of distributed leadership is straightforward. To direct and complete several tasks that vary in size, complexity, and scope, this style of leadership relies on various sources of leadership within the organization (Elmore, 2000; Hoy \& Miskel, 2013). In this study, the discussion of distributed leadership focused on four dimensions of Elmore (2000) distributed leadership theory. Goal, vision, and school objective; school culture; leadership practice; and sharing the burden are the four dimensions of dispersed leadership.

\section{Literature Review}

Many models have been developed by the previous scholar to discuss organizational commitment. This research used Mayer and Allen's model (1990) or known as ThreeCommitment Model (TCM). Organizational commitment is an attitude, a belief, a sense of attachment to and in an organization (Meyer \& Alllen, 2004; Ling, 2016). Affective commitment, continuance commitment, and normative commitment are three components of Meyer and Allen's (1991) organizational commitment model. The first dimension is an affective commitment or also known as moral commitment is refers to the employees' identification with and attachment to the organization (Mayer and Allen, 1997). For continuance commitment, it is the employees' feeling to be committed to the organization due to the cost they must pay for leaving the organization. The sense of commitment among the employee is because of compliance or conformity because of rewards and punishment. Employees believe that remaining and working in the company is their obligation and responsibility as a result of this form of dedication (Meyer \& Allen, 1991).

The professional learning community's mission, vision, and goals are considered the foundation. A shared vision, according to Neuman and Simmons (2000), includes concrete expectations with an emphasis on student achievement. School vision has also been defined as an educational forum in which the organization's values shape the organization's norms (Gordon, 2005). Teachers are empowered to cooperate, participate in school-based decisionmaking, participate in professional development, and promote the leadership of classroom 
teachers in a community that supports distributed leadership (Murphy, 2005). If the organization pursues a shared goal, understands the change process, builds partnerships, fosters knowledge building, and aims for continuity, school environments can change as an added advantage (Fullan, 2001). The idea behind shared responsibility is that leadership should not be the responsibility of a single person, but rather should be shared among many people in an organization (Storey, 2004). There is no single best way to determine the effectiveness of a program implemented in school, neither the best method to present and describe the adequacy of every provision in a program implementation (Mustakim, 2018); the way school leaders identify, present, and carry out their interactions with others in the process of leading is called practice leadership (Gordon, 2005, p. 41).

Previous research has shown that supportive principals improve teachers' organizational engagement (Hulpia \& Devos, 2010; Nguni et al., 2006; Park, 2005; Tsui \& Cheng, 1999). Hulpia and Devos (2009) compared four schools with highly committed teachers to four schools with low committed teachers. Different leadership strategies affected organizational engagement, according to the findings. Teachers said they were more committed to the school if the leaders were approachable, dealt with issues quickly or encouraged teachers to engage, and closely monitored teachers' daily activities. The quality of positive leadership, teamwork within the leadership team, and participatory decision-making are all important factors in teachers' organizational engagement (Hulpia, Devos, \& Van Keer, 2011).

Rabindarang and Bing (2012) studied the relationship between distributed leadership and organizational commitment among 31 teachers from seven vocational colleges. The result showed there is a significant correlation between distributed leadership and organizational commitment. Ali and Salisu (2015) researched distributed leadership and teacher organizational commitment. They found that a significant relationship between these two variables. Research by Marlia and Yahya (2016) among 298 teachers in Kedah showed distributed leadership had a significant correlation with teachers' organizational commitment. However, the result just indicated the weak correlation between distributed leadership and organizational commitment at $r=.31$ when $p<.01$. Aboudahr and Jiali (2019) used the Distributed Leadership Inventory (DLI) developed by Hulpia et al. (2009) and the Organizational Commitment Questionnaire (OCQ) developed by Mowday et al. to study 896 teachers in Baiyun districts in Guangzhou city (1979). The findings showed that the school's dispersed leadership and teachers' organizational engagement were linked positively.

Today, teachers used social media to express their stress and problem at their schools. Besides, there is also a newspaper report about teachers nowadays are unhappy with their job and some teachers choose to retire early (Harian, 2016). Effective solutions need to take by the authorities to ensure all teachers are committed because commitment among teachers can influence student academic achievement and school performance (Mohamad, Kasim, Zakaria, \& Nasir, 2016). Previous literature found leadership influences organizational commitment (Hulpia \& Devos, 2010; Rabindarang \& Bing, 2012; Marlia \& Yahya, 2016). And, this study was conducted to get concrete data on the significant correlation between organizational commitment and distributed leadership among secondary school teachers in Malaysia. 


\section{Methodology}

This research employs a quantitative approach to provide a deeper understanding of the research issues. The primary objective of this research is to identify the significant correlation between organizational commitment and distributed leadership among secondary school teachers in Peninsular Malaysia. Specifically, the study seeks to:

[1] identify the level of organizational commitment among secondary school's teachers in Malaysia,

[2] identify the level of distributed leadership among schools' teachers in Malaysia, and

[3] determine the relationship between distributed leadership and organizational commitment among secondary schools' teachers in Malaysia.

A survey was administered among 350 secondary school teachers from a selected school in Peninsular Malaysia using a simple random stratified sampling technique. This research utilized Three-Component Model (TCM) to measure organizational commitment and Distributed Leadership Readiness Scale (DLRS) to measure distributed leadership. Data obtained in this study were analyzed using a descriptive statistic to explain the level of variables and inferential statistics to find a correlation between these variables.

\section{Results and Analysis}

Findings of the level of Organizational Commitment among Secondary School Teachers in Peninsular Malaysia indicated that all dimensions of organizational commitment are at a moderate level. The highest is an affective commitment with $M=3.70, S D=0.49$. Then it was followed by continuance commitment with $M=3.41, S D=0.54$. Next is a normative commitment that is $M=2.98, S D=0.52$. Overall, the level of organizational commitment is moderate with $\mathrm{M}=3.37, \mathrm{SD}=0.40$. This means organizational commitment among secondary school teachers in Peninsular Malaysia is at a moderate level. Details about this finding are illustrated in Table 1:

Table 1: Level of Organizational Commitment

\begin{tabular}{llll}
\hline Descriptive Statistic & Mean & SD & Level \\
\hline Affective Commitment & 3.74 & 0.50 & Moderate \\
Continuance Commitment & 3.26 & 0.55 & Moderate \\
Normative Commitment & 2.99 & 0.52 & Moderate \\
\hline Overall Organizational Commitment & $\mathbf{3 . 3 7}$ & $\mathbf{0 . 4 0}$ & Moderate \\
\hline
\end{tabular}

Note: Low (1-2.33), Moderate (2.34 - 3.66), High (3.67-5), $N=350$

Findings related to the level of Distributed Leadership among Secondary School Teachers in Peninsular Malaysia shows that all dimension is at a high level. The highest is school culture with $M=4.19, S D=0.60$. Then it followed by dimension sharing responsibility with $M=4.15, S D=0.62$. Next is dimension mission, vision, and school objective that is $M=4.09$, $S D=0.58$. The least but still at a high level is practice leadership with $M=4.07, S D=0.70$. Overall, the level of distributed leadership is high with $M=4.12, S D=0.57$. This mean, all secondary school principal in Peninsular Malaysia practiced distributed leadership at a high level. Details about this perception of secondary schools' teachers towards their principal Distributed Leadership is illustrated in Table 2: 
Table 2: Level of Distributed Leadership

\begin{tabular}{|c|c|c|c|}
\hline Descriptive Statistic & Mean & SD & Level \\
\hline $\begin{array}{l}\text { Mission, Vision, and School Objective } \\
\text { Determination } \\
\text { Partnership }\end{array}$ & 4.09 & .58 & High \\
\hline $\begin{array}{l}\text { School Culture } \\
\text { The effect on student achievement } \\
\text { Cooperation and Collaboration } \\
\text { Professional Learning Communities }\end{array}$ & 4.19 & .60 & High \\
\hline $\begin{array}{l}\text { Sharing of Responsibility } \\
\text { Decision Making } \\
\text { Collaborative Decision Making } \\
\text { Performance Evaluation } \\
\text { Professional Development } \\
\end{array}$ & 4.15 & .62 & High \\
\hline Practice Leadership & 4.06 & .70 & High \\
\hline Principalship & 4.21 & .70 & High \\
\hline Middle Leader & 3.94 & .64 & High \\
\hline Overall Distributed Leadership & 4.12 & 0.57 & High \\
\hline
\end{tabular}

Note: Low (1-2.33), Moderate (2.34 - 3.66), High (3.67 - 5), $\mathrm{N}=350$

Findings concerning the Significant Correlation between Distributed Leadership and Organizational Commitment among Secondary School Teachers in Peninsular Malaysia are highlighted in Table 3. This finding was analyzed using Pearson Correlation. The result of the correlation coefficient is based on Cohen (1998). From Table 3, results show there is a positive significant correlation between distributed leadership and organizational commitment $(r=.556, p=.000)$ at the strong level.

Table 3: Correlation between distributed leadership and organizational commitment

\begin{tabular}{llll}
\hline Variables & $\mathbf{r}$ & $\mathbf{P}$ & Level \\
\hline Distributed Leadership & $.556^{* *}$ & .000 & Strong \\
Organizational Commitment & &. & \\
\hline
\end{tabular}

\section{Discussion}

Generally, findings of this study indicated the level of organizational commitment among secondary school teachers in Malaysia is moderate, similarly as highlighted in a study administered by Nazari, Zaidatol, Ramli, and Khairuddin (2012), Colak, Altinkurt, and Yilmaz (2014), Ramalho Luz, de Paula, and de Olivera (2016), Akdemir and Ayik (2017), and Mohammed Aboudahr and Jiali (2019). While outcomes from distributed leadership show all four dimensions are at the high level and it contributed the high level for overall distributed leadership, similar to result encountered in the study conducted by Rahman (2015); Harun et al (2016); Marlia and Yahya (2016); Mayan and Mansor (2020).

According to Powell and Meyer (2004) in Ling (2016), Malaysian teachers are very much influenced by continuance commitment which is related to the investment for this context is pension, benefits, seniority, and special competencies that the employee gained by working for a long time in the organization. Workers feel committed to their company 
because of the costs they believe are associated with quitting, while employees interpret their relationship with the organizations of whether their beliefs and interests are congruent with those of the organization's loyalty (Meyer \& Allen, 1991; Wong \& Tong, 2014). Result in this study showed only affective commitment is at a high level meanwhile the other two dimensions, continuance commitment, and normative commitment, is at a moderate level. The result shows that secondary school teacher in Malaysia has a moderate level towards organizational commitment and show the high level of affective commitment compared to the continuance commitment.

The results show there is a positive significant correlation between distributed leadership and organizational commitment at the strong level. This finding is similar to the research conducted by Ali and Salisu (2015); Marlia and Yahya (2016); Baddiri and Abdullah (2017), and Samancioglu, Baglibel, and Erwin (2020) that shows a significant correlation between distributed leadership and organizational commitment. This result shows, the high level of distributed leadership practice and organizational commitment among secondary school teachers are at a moderate level.

\section{Conclusion}

In conclusion, this research focused on organizational commitment and distributed leadership among secondary school teachers in Peninsular Malaysia. Organizational commitment is important to study because a committed teacher can produce more promising learning outcomes among students and previous research proved it influenced to dent academic achievement and school effectiveness (Park, 2005; Ling, 2016). This research found that the level of organizational commitment among secondary school teachers in Peninsular Malaysia is at a moderate level. Meanwhile, the perception of teachers toward distributed leadership practice by their principals at a high level. There is a significant correlation between distributed leadership and organizational commitment among secondary school teachers in Peninsular Malaysia.

The low level of motivation among teachers is extensively recognized as one of the most pressing challenges in Malaysia's educational system. Several studies have identified several elements that contribute to this issue. But what about the schools with the lowest levels of teacher dissatisfaction? One key element that could be contributing to this disparity is the usage of distributed leadership in schools, which refers to principals that share power and responsibility with their teachers. This strategy has been found to be an effective strategy to promote organizational commitment among secondary school teachers in Peninsular Malaysia by helping to create relationships between principals and teachers so that both feel a sense of ownership in academic accomplishment.

The finding of this research contributed to the existing knowledge of organizational commitment and distributed leadership theories based on Malaysian culture and thought. The result of this research shows organizational commitment is at moderate level. Continuance commitment and normative commitment score moderate level while affective commitment is at high level. This means secondary school teachers in Peninsular Malaysia committed to their school because of their positive emotional attachment to the organization and they willing to commit to school without concerning of material benefit. 
This research implies that teachers' modest organizational engagement is influenced by distributed leadership approaches. Distributed leadership is highlighted in the Malaysia Education Blueprint as one of the finest leadership style methods based on best practices in developed nations. To promote teacher organizational engagement, principals should strengthen their abilities to adopt a dispersed leadership style at work and establish an exciting and inclusive environment. Aside from that, the administrator should put in place a program like continual professional development to keep teachers engaged and prevent burnout.

\section{References}

Akdemir, O. A., \& Ayik, A. (2017). The impact of distributed leadership behaviors of school principals on the organizational commitment of teachers. Universal Journal of Educational Research, 5(12B), 18-26. Retrieved from https://eric.ed.gov/?q=organizational+commitment+and+distributed+leadership\&id $=$ EJ1165487

Baddiri B., Abdullah M. K. (2017). Analisis kepimpinan distributif pengarah dan komitmen organisasi dalam Kalangan pengajar di Kolej Sains Kesihatan Bersekutu (KSKB) Kuching Sarawak. International Journal of Education, Psychology and Counseling. 2(6), 291299.

Colak, I., Altinkurt, Y., \& Yilmaz, K. (2014). The relationship between teachers' teacher leadership roles and organizational commitment levels. Educational Process: International Journal, 35-51.

Dee, J. R., Henkin, A. B., \& Singleton, C. A. (2006). Organizational commitment of teachers in urban schools: examining the effects of team structures. Urban Education, 603-627.

Elmore, R. (2000). Building a new structure for school leadership. Washington, DC: The Albert Shanker Institute.

Fullan, M. G. (2001). The new meaning of educational change (3rd ed.). New York: Teachers College Press.

Gordon Z. V. (2005). The effect of distributed leadership on student achievement. PhD Dissertation. New Britain. Central Connecticut State University

Ali, H. M., \& Salisu, A.Y. (2015). Distributed leadership and empowerment influences on teachers organizational commitment. Academic Journal of Interdisicplinary Studies MCSER Publishing, Vol. 4 No. 1. S1, Rome-Italy. ISSN 2281-3993

Harun, A., Basri, R., Pihie, Z. A., \& Asimiran, S. (2016). Hubungan antara amalan kepemimpinan distributif pengetua dan kepemimpinan guru di sekolah menengah. International Journal of Education and Training (InjET), 2(2), 1-13.

Hoy, W. K., \& Miskel, C. G. (2013). Educational administration (9th Edition ed.). New York: McGraw Hill.

Hulpia, H., and Devos, G. (2009). Exploring the link between distributed leadership and job satisfaction of school leaders. Educational Studies 35 (2): 153-171. doi:10.1080/03055690802648739

Hulpia, H., \& Devos, G. (2010). How distributed leadership can make a difference in teachers' organization.Teaching and Teacher Education, 565-575.

Hulpia, H., Devos, G., \& Van Keer, H. (2011). The relation between school leadership from a distributed perspective and teacher's organizational commitment: Examining the source of the leadership function. Educational Administration Quarterly, 782-771.

Ibrahim, M. A., Wan Sulaiman, W. S., Ibrahim, N. I., Abdul Malek, M. A., \& Bausing, A. (2018). 
Pengaruh keadilan organisasi, kepuasan kerja, komitmen organisasi dan prestasi tugas terhadap tingkah laku kewargaan organisasi dalam kalangan pensyarah. Jurnal Psikologi Malaysia, 75-87.

Ling, T. P. (2016). Self-efficacy as a mediator in the relationship between transformational leadership and organizational commitment among secondary school teachers in Central Region, Peninsular Malaysia. Unpublished Doctoral Thesis.Universiti Putra Malaysia, Serdang.

Malaysian Ministry of Education. (2013). Malaysia Education Blueprint 2013-2025. Putrajaya: MOE.

Marlia, J., \& Yahya, D. (2016). Praktis kepimpinan distributif dan komitmen terhadap organisasi berdasarkan Kohort generasi guru. Proceeding of ICECRS (pp. 275-286). Kedah: Universiti Utara Malaysia.

Mayan, M. P., \& Mansor, M. (2020). Hubungan antara amalan kepimpinan distributif dengan efikasi kendiri dan komuniti pembelajaran profesional guru di Kuala Lumpur. $\begin{array}{lll}\text { Management } \quad \text { Research } & \text { 70-83. }\end{array}$ https://doi.org/10.37134/mrj.vol9.2.6.2020

Metcalfe, B., \& Dick, G. (2002). Is the force still with her? Gender and commitment in the police. Women in Management Review, 392-403.

Meyer, J. P., \& Allen, N. (1984). Testing the "side-bet theory" of organizational commitment: Some methodological considerations. Journal of Applied Psychology, 372-378.

Meyer, J. P., \& Allen, N. J. (1991). A three-component conceptualization of organizational commitment. Human Resource Management Review, 1(1), 61-89.

Meyer, J., \& Allen, N. (1991). A three-component conceptualization of organizational commitment. Human Resources Management Review, 81-89.

Meyer, J. P., \& Allen, N. J. (1997). Commitment in the workplace: theory, research, and application. Newbury Park, CA: Sage Publication.

Meyer, J. P., \& Alllen, N. J. (2004). TCM Employee Commitment Survey Academic User Guide. Meyer, J. P., Allen, N., \& Gellaty, I. R. (1990). Affective and continuance commitment to the organization:evaluation of measures and analysis of concurrent and time-lagged relations. Journal of Applied Psychology, 75(6), 710-720.

Meyer, J. P., \& Herscovitch, L. (2001). Commitment in the workplace. Toward a general model. Human Resource Management Review, 3(11), 299-326.

Meyer, P. J., \& Smith, C. A. (2000). HRM practices and organizational commitment: A test of a mediation model. Canadian Journal of Administrative Sciences, 17, 319-331.

Meyer, P. J., Stanley, D. J., Herscovitch, L., \& Topolnytsky, L. (2002). Affective, continuance, and normative commitment to the organization: A meta-analysis of antecedents, correlates, and consequences. Journal of Vocational Behavior, 61, 20-52.

Aboudahr, M. S., \& Jiali, L. (2019). The relationship between distributed leadership and teachers' organizational commitment in Guangzhou city, China. Journal of Educational and Management Studies, 1-5.

Mohamad, R., Kasim, A. L., D., Zakaria, S., \& Nasir, F. M. (2016). Komitmen guru dan kepuasan kerja guru di sekolah menengah harian berprestasi tinggi dan berprestasi rendah di daerah Kota Bharu, Kelantan. International Seminar on Generating Knowledge Through Research (pp. 863-874). Keadah: Universiti Utara Malaysia.

Murphy, J. (2005). Connecting teacher leadership and school improvement. Thousand Oaks, London, New Delhi:Corwin Press, Sage

Mustakim, S. S., Sulaiman, T., Manaf, U. K. A., Minghat, A. D., Rabindarang S. (2020). An 
evaluation on strategic Plan of transformation in Vocational Education (SPTVE) 20112025 and Its Relevance Towards the Thrive of 4th Industrial Revolution. Solid State Technology, Vol. 63(6), 1008-1016.

Mustakim, S. S. (2018). Gauging the management's role in the implementation of literature programme. International Journal of Academic Research in Business and Social Sciences, 8(7), 750-762

Nazari, K., Zaidatol, A.L.P., Ramli, B., \& Idris, Khairuddin. (2012). The level of organizational commitment among lecturers in technical and Vocational Colleges in Iran. Pertanika Journal of Social Science and Humanities. 20. 21-40.

Neuman, M., \& Simmons, W. (2000). Leadership for student learning. Phi Delta Kappan, 82, 9 13.

Nguni, S., Sleegers, P., \& Denessen, E. (2006). Transformational and transactional leadership effects on teachers' job satisfaction, organizational commitment, and organizational citizenship behavior in primary schools: The Tanzanian case. School Effectiveness and School Improvement, 17, 145-177

Park, I. (2005). Teacher commitment and its effects on student achievement in American High Schools. Educational Research and Evaluation, 11, 461-485

Powell, D. M., \& Meyer, J. P. (2004). Side-Bet Theory and the Three-Component Model of organizational commitment. Journal of Vocational Behavior, 65, 157-177

Rahman, Z. A. (2015). Amalan kepimpinan distributif dalam kalangan pengetua dan hubungannya dengan kepuasan kerja guru di selangor. Tanjung Malim: Universiti Pendidikan Sultan Idris.

Luz, R. C. M., de Paula, S. L., \& de Olivera, B. (2018). Organizational commitment, job satisfaction and their possible influences on intent to turnover. Revista de Gestão, 25(1), 84-101. doi:DOI 10.1108/REGE-12-2017-008

Rabindarang, S., \& Bing, K. W. (2012). Hubungan kepemimpinan distributif terhadap komitmen:organisasi dan tekanan kerja dalam pendidikan teknik dan vokasional. National Research \& Innovation Conference for Graduate Students in Social Sciences (GS-NRIC 2012), (pp. 489-498). Melaka.

Rehman, S., Shareef, A., Mahmood, A., \& Ishaque, A. (2012). Perceived leadership styles and organizational commitment. Interdisciplinary Journal of Contemporary Research in Business, 4, 616-626. Retrieved from http://ijcrb.webs.com

Ross, J. A., \& Gray, P. (2006). Transformational leadership, teacher commitment, and teacher efficacy.

Saeed, R., Lodhi, R. N., Ahmed, S., ur Rehman, M., Dustgeer, F., \& Sami, A. (2013). The role of communication in organizational change. Management and Administrative Sciences Review, 2(6), 689-694.

Samancioglu, M., Baglibel, M., \& Erwin, B. J. (2020). Effects of distributed leadership on teachers' jobsatisfaction, organizational commitment and organizational citizenship. Pedagogical Research, 5(2), 2-9. Retrieved from https://doi.org/10.29333/pr/6439

Harian, S. (2016). Ramai sudah tak seronok mengajar. Shah Alam

Storey, A. (2004). The problem of distributed leadership in schools. School Leadership and Management 24(3): 249-265

Tsui, K. T., \& Cheng, Y. C. (1999). School organizational health and teacher commitment: A contingency study with multi-level analysis. Educational Research and Evaluation, 5, 249-268

Sulaiman, W., Ibrahim, M. A., \& Mariappa, M. S. (2013). Peranan tingkah laku kewargaan 
organisasi sebagai mediator dalam hubungan antara komitmen organisasi dan prestasi tugas. Journal Psikologi dan Pembangunan Manusia(1), 29-35.

Wong, A., \& Tong, C. (2014). Evaluation of organizational commitment models and their components in Asian cities. International Journal of Human Resource Studies, 4(2), 6696. 